\title{
Pengaruh Model Pembelajaran Kooperatif Tipe Group Investigation Berbantuan Asesmen Kinerja Terhadap Keterampilan Proses Sains
}

\author{
Ni L.P.W Wahyuni1 ${ }^{*}$, I M.C. Wibawa², N.T Renda ${ }^{3}$
}

1,2,3 Jurusan Pendidikan Guru Sekolah Dasar, Universitas Pendidikan Ganesha, Singaraja, Indonesia

\section{ARTICLEIN} $\mathrm{F} \mathrm{O}$

\section{Article history:}

Received 09 May 2018

Received in revised form

19 June 2018

Accepted 19 July 2018 Available online 25

August 2018

\section{Kata Kunci:}

group investigation keterampilan proses sains

Keywords: group investigation science process skill

\section{A B S TR A K}

Penelitian ini bertujuan untuk mengetahui pengaruh model pembelajaran kooperatif tipe group investigation berbantuan asesmen kinerja terhadap keterampilan proses sains siswa kelas V semester II di SD Gugus II Kecamatan Buleleng tahun pelajaran 2017/2018. Populasi penelitian ini adalah seluruh siswa kelas V di SD Gugus II Kecamatan Buleleng Tahun Pelajaran 2017/2018 yang berjumlah 137 orang. Pengambilan sampel dalam penelitian ini menggunakan teknik group random sampling dengan teknik undian. Sampel penelitian ini yaitu siswa kelas V SD Negeri 1 Penarukan yang berjumlah 21 orang dan siswa kelas V SD Negeri 2 Penarukan yang berjumlah 25 orang. Instrumen yang digunakan dalam penelitian ini yaitu tes keterampilan proses sains berupa soal uraian. Data yang diperoleh dianalisis dengan menggunakan analisis statistik deskriptif dan analisis statistik inferensial yaitu uji-t. Hasil penelitian menunjukkan bahwa terdapat perbedaan keterampilan proses sains antara kelompok siswa yang dibelajarkan dengan model pembelajaran kooperatif tipe group investigation berbantuan asesmen kinerja dan kelompok siswa yang dibelajarkan dengan pembelajaran konvensional pada siswa kelas V semester II di SD Gugus II Kecamatan Buleleng tahun pelajaran 2017/2018 yang dibuktikan dengan nilai $t_{\text {hitung }}$ $(5,771)>t_{\text {tabel }}(2,015)$. Berdasarkan hasil penelitian tersebut dapat disimpulkan bahwa model pembelajaran kooperatif tipe group investigation berbatuan asesmen kinerja berpengaruh terhadap keterampilan proses sains siswa kelas V semester II di SD Gugus II Kecamatan Buleleng tahun pelajaran 2017/2018.

\section{A B S TR A C T}

The purpose of this research is to know the impact of cooperative learning model of group investigation type assisted performance assessment to science process skill of five grade student in two semester of SD Gugus II Buleleng district in academic year 2017/2018. The population of this research is all of five grade student of SD Gugus II Buleleng district that consist of 137 student. The sampling of this research is by using group random sampling with lottery technique. The sample of this research is five grade students of SD Negeri 1 Penarukan that consist 21 students and the five grade students of SD Negeri 2 Penarukan which consist of 25 students. The instrument that used in this research is science process skill test in form of essay question. The data obtained then analyzed by statistical analysis description and statistical analysis inferential that is $t$-test. The result of research show score there is a difference between science prosess skill the group of students that taught by cooperative cooperative learning model of group investigation type assisted performance assessment and the group of students that taught by conventional learning to the five grade student II semester of $S D$ Gugus II Buleleng district in academic year 2017/2018as devidenced by $t_{\text {count }}(5,771)>t_{\text {table }}$ $(2,015)$. Based on the result of research can be concluded that the cooperative learning which type group investigation assisted performance assessment can effect to the science process skill of the five grade students II semester of SD Gugus II Buleleng distict in academic year 2017/2018.

Copyright (C) Universitas Pendidikan Ganesha. All rights reserved.

\footnotetext{
Corresponding author.

E-mail addresses: putuwiwikwahyuni70@gmail.com (Putu Wiwik Wahyuni)
} 


\section{Pendahuluan}

Indonesia merupakan salah satu negara berkembang di kawasan Asia, yang sedang giat melaksanakan pembangunan di segala bidang. Dalam melaksanakan pembangunan, Indonesia memerlukan sumber daya manusia yang berkualitas yang dapat diperoleh melalui pendidikan. Melihat pentingnya pendidikan, pemerintah melakukan berbagai upaya untuk meningkatkan kualitas pendidikan di Indonesia, diantaranya adalah meningkatkan anggaran untuk pendidikan, mulai aktif memberikan penyuluhan terhadap guru, menjalankan program sertifikasi guru, meningkatkan standar kelulusan minimal, dan pembenahan kurikulum.

Dalam rangka menyukseskan upaya pemerintah, diperlukan kesadaran dan kerjasama dari berbagai pihak pelaksana pendidikan. Salah satu pelaksana pendidikan adalah guru. Guru merupakan kunci dalam penyelenggaraan pembelajaran. Tanpa seorang guru, maka proses pembelajaran akan terhambat bahkan pembelajaran tidak dapat berlangsung. "Setiap guru memerlukan kreativitas untuk menumbuh-kembangkan daya imajinasi dan berpikir bagi peserta didiknya" (Sugiyanto, 2010:12). Oleh karena itu diperlukan upaya guru untuk menciptakan pembelajaran menjadi aktif, inovatif, kreatif, efektif, dan menyenangkan.Pembelajaran yang demikian dapat diwujudkan dengan menerapkan berbagai strategi, pendekatan, metode, teknik, maupun model pembelajaran yang disesuaikan dengan materi pelajaran dan kurikulum yang berlaku. Setiap mata pelajaran memiliki karakteristik materi yang berbedabeda, sehingga guru dituntut untuk inovatif dan kreatif. Selain memahami karakteristik materi guru juga hendaknya memahami karakter siswa.

Berdasarkan UU No. 20 Tahun 2003, Bab X Pasal 37 Ayat 1, diketahui bahwa salah satu mata pelajaran yang diajarkan di SD adalah IPA. "IPA adalah suatu kumpulan pengetahuan tersusun secara sistematis, penerapannya secara umum terbatas pada gejala-gejala alam, lahir dan berkembang melalui metode ilmiah seperti observasi dan eksperimen serta menuntut sikap ilmiah seperti rasa ingin tahu, terbuka, jujur, dan sebagainya" (Trianto, 2010:136).Berdasarkan pengertian tersebut dapat diketahui bahwa IPA sangat penting dibelajarkan pada jenjang SD.

Pembelajaran IPA di SD hendaknya memberikan kesempatan sebanyak-banyaknya kepada siswa untuk mengembangkan keterampilan proses. Keterampilan proses sains adalah "sejumlah keterampilan untuk mengkaji fenomena alam dengan cara-cara tertentu untuk memperoleh ilmu dan pengembangan ilmu itu selanjutnya" (Bundu, 2006:12).Melatih keterampilan proses sains merupakan salah satu upaya penting untuk memperoleh keberhasilan belajar siswa yang optimal. Materi pelajaran akan lebih mudah dipelajari, dipahami, dihayati, dan diingat dalam waktu yang relatif lama apabila siswa sendiri memperoleh pengalaman langsung dari peristiwa belajar tersebut melalui pengamatan atau eksperimen.Melalui keterampilan proses siswa berupaya untuk menemukan dan mengembangkan sendiri konsep dalam suatu materi. Dengan berusaha untuk mencari pemecahan masalah secara mandiri akan memberikan suatu pengalaman konkret, pengalaman tersebut dapat digunakan untuk memecahkan masalah-masalah serupa (Trianto, 2010:7). Jadi peran guru dalam proses pembelajaran di kelas adalah sebagai pembimbing, motivator, fasilitator, model, sekaligus evaluator. Namun kenyataannya, pembelajaran IPA di SD cenderung masih berpusat pada guru. Guru yang lebih aktif memberikan informasi sedangkan siswa hanya menerima informasi yang diberikan oleh guru.

Berdasarkan wawancara dan observasi terhadap kegiatan pembelajaran IPA di Kelas V SD Gugus II Kecamatan Buleleng pada tanggal 8 sampai 12 Januari 2018, nampak bahwa 1) guru dalam proses pembelajaran cenderung menggunakan metode ceramah, penugasan, dan tanya jawab, 2) siswa kurang aktif dalam proses pembelajaran, 3) siswa jarang melakukan kegiatan mengamati dan percobaan, 4) penilaian dalam proses pembelajaran IPA masih berfokus pada penilaian hasil belajar ranah kognitif.

Melihat permasalahan tersebut, guru perlu berusaha untuk menciptakan pembelajaran yang mampu membangkitkan semangat belajar siswa, bermakna, dan menyenangkan. Selain itu, pembelajaran juga harus memberdayakan siswa semaksimal mungkin dalam proses pembelajaran. Untuk mengatasi permasalahan tersebut, diperlukan inovasi dalam penyajian pembelajaran IPA di kelas seperti menerapkan model pembelajaran yang dapat mendukung proses belajar mengajar. Model pembelajaran yang dapat membantu siswa mengatasi rendahnya partisipasi dan keterampilan proses sains siswa adalah model pembelajaran yang dapat melibatkan siswa dalam menyelidiki sesuatu. Salah satu model pembelajaran yang melibatkan siswa dalam proses penyelidikan adalah model pembelajaran kooperatif tipe group investigation.

Menurut Kurniasih (2016:80) "group investigation adalah salah satu bentuk model pembelajaran kooperatif yang menekankan pada partisipasi dan aktivitas siswa untuk mencari sendiri materi (informasi) pelajaran yang akan dipelajari". Dalam penerapan model pembelajaran kooperatif tipe group investigation, siswa aktif dalam menggali, membangun, dan mengembangkan konsep, sedangkan guru hanya memfasilitasi, membimbing, dan memotivasi siswa selama proses pembelajaran. 
Dalam pelaksanaan pembelajaran dengan menggunakan model pembelajaran kooperatif tipe group investigation, guru perlu mengetahui berhasil atau tidaknya proses pembelajaran yang terjadi yang nantinya digunakan sebagai refleksi dalam melaksanakan pembelajaran berikutnya. Suatu proses mengumpulkan informasi yang berkaitan dengan variabel-variabel penting dalam proses pembelajaran sebagai bahan pengambilan keputusan oleh seorang guru untuk memperbaiki proses atau hasil belajar peserta didik disebut dengan asesmen (Uno, dkk dalam Marhaeni, dkk., 2017:47). Salah satu asesmen yang memperhatikan aktivitas yang dilakukan adalah asesmen kinerja. Asesmen kinerja merupakan penilaian dengan berbagai macam tugas dan situasi, dimana peserta didik diminta untuk mendemontrasikan pemahaman dan mengaplikasikan pengetahuan yang mendalam, serta keterampilan dalam berbagai macam konteks (Majid dalam Marhaeni, dkk., 2017:48). Dengan kata lain asesmen kinerja merupakan penilaian terhadap kegiatan siswa dalam situasi yang sebenarnya melalui proses pengamatan langsung. Oleh karena itu, dalam penelitian ini model pembelajaran kooperatif tipe group investigation dikombinasikan dengan asesmen kinerja yang bertujuan agar keterampilan proses sains siswa dapat dinilai dengan objektif sesuai dengan kriteria keterampilan proses sains.Dalam penelitian ini keterampilan proses sains yang digunakan hanya 4 yaitu keterampilan mengamati, memprediksi, merancang dan melakukan percobaan, dan mengomunikasikan. Keterampilan proses sains tersebut dipilih karena keterampilan-keterampilan proses sains tersebut merupakan keterampilan proses sains dasar yang menjadi fokus penguasaan di SD (Bundu, 2006:19).

Berdasarkan uraian tersebut, model pembelajaran group investigation berbantuan asesmen kinerja diasumsikan berpengaruh terhadap keterampilan proses sains siswa. Oleh karena itu, akan dilaksanakan suatu penelitian eksperimen yang berjudul Pengaruh Model Pembelajaran Kooperatif tipe Group Investigation Berbantuan Asesmen Kinerja terhadap Keterampilan Proses Sains Siswa Kelas V Semester II di SD Gugus II Kecamatan Buleleng Tahun Pelajaran 2017/2018.

\section{Metode}

Penelitian ini merupakan penelitian eksperimen. Penelitian ini dikategorikan penelitian eksperimen semu (quasi eksperiment) karena tidak semua variabel muncul dan kondisi eksperimen dapat diatur dan dikontrol secara ketat. Penelitia ini dilaksanakan dalam dua tahap yaitu tahap persiapan eksperimen dan tahap eksperimen. Penelitian ini mengikuti desain penelitian kuasi eksperimen dengan rancangan non-equivalent post test only kontrol group design.

Populasi dalam penelitian ini adalah seluruh siswa kelas V Gugus II Kecamatan Buleleng dengan jumlah siswa 137 orang. Sebelum menentukan sampel terlebih dahulu dilakukan uji kesetaraan dengan menganalisis nillai keterampilan proses sains awal siswa menggunakan rumus ANAVA satu jalur dengan bantuan SPSS 21.0 for windows. Berdasarkan hasil analisis diperoleh hasil bahwa signifikansi nilai keterampilan proses sains pada populasi tersebut adaah 0,183 ebih besar dari 0,05 $(0,183>0,05)$. Artinya nilai keterampian proses sains siswa kelas V di SD Gugus II Kecamatan Buleleng setara.Setelah diketahui kelima sekolah setara maka dilakukan pemilihan sampel.Dalam menentukan sampel teknik yang digunakan adalah grouprandom sampling dengan menggunakan teknik undian.Berdasarkan pengundian tersebut diperoleh sampel yaitu seluruh siswa kelas V di SD Negeri 1 Penarukan debagai kelompok eksperimen dan seluruh siswa kelas V di SD Negeri 2 Penarukan sebagai kelompok kontrol.

Dalam penelitian ini terdiri dari dua variabel yaitu variabel bebas dan variabel terikat. Variabel terikat dalam penelitian ini adalah keterampilan proses sains sedangkan variabel bebas adalah model pembelajaran kooperatif tipe group investigationberbantuan asesmen kinerja pada kelompok eksperimen dan pembelajaran konvensional pada kelompok kontrol.

Data yang dikumpulkan dalam penelitian ini yaitu keterampilan proses sains siswa kelas V. Metode yang digunakan untuk mengumpulkan data keterampilan proses sains adalah metode tes. Instrumen yang digunakan dalam penelitian ini yaitu tes keterampilan proses sains. Untuk mengetahui kualitas isinya, terlebih dahulu dilakukan uji validitas isi (uji pakar) yang dilakukan oleh dua pakar guna mendapatkan kualitas tes yang baik. Setelah itu dilakukan uji coba instrumen.

Data yang diperoleh dianalisis dengan menggunakan metode analisis deskriptif dan statistik inferensial yaitu uji-t. Analisis statistik deskriptif digunakan untuk menghitung mean, median, modus, standar deviasi, dan varians pada kelas eksperimen dan kelas kontrol, sedangkan metode analisis inferensial yang digunakan adalah uji-t. Namun, sebelum dihitung menggunakan uji-t terlebih dahulu melakukan uji prasyarat yaitu normalitas dan homogenitas varians. Dalam penelitian ini rumus uji-t yang digunakan yaitu polled varians. 


\section{Hasil Dan Pembahasan}

Berdasarkan hasil analisis data dengan analisis statistik deskriptif pada kelas eksperimen dan kontrol, diperoleh deskripsi data keterampilan proses sains kelompok eksperimen dan kelompok kontrol disajikan pada Tabel 1 berikut ini.

Tabel 1. Deskripsi Data Keterampilan Proses Sains Kelompok Eksperimen dan Kelompok Kontrol

\begin{tabular}{lll}
\hline Statistik Deskriptif & $\begin{array}{l}\text { Kelompok } \\
\text { Eksperimen }\end{array}$ & $\begin{array}{l}\text { Kelompok } \\
\text { Kontrol }\end{array}$ \\
\hline $\mathrm{N}$ & 21 & 25 \\
\hline Skor Maksimal & 31 & 28 \\
\hline Skor Minimal & 19 & 14 \\
\hline Mean & 26,14 & 20,56 \\
\hline Median & 26,68 & 20,32 \\
\hline Modus & 27,64 & 19,75 \\
\hline Standar Deviasi & 3,22 & 3,21 \\
\hline Varians & 10,35 & 10,28 \\
\hline
\end{tabular}

Mean, median, modus keterampilan proses sains kelompok eksperimen dan kelompok kontrol selanjutnya disajikan dalam bentuk histogram. Histogram data keterampilan proses sains kelompok eksperimen dapat dilihat pada Gambar 1 berikut.

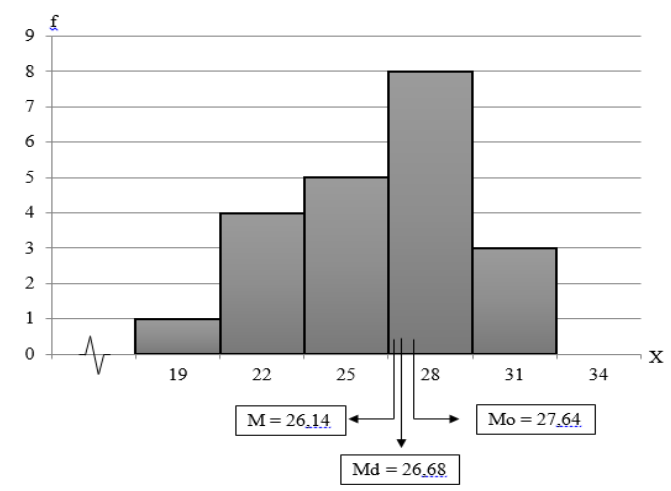

Gambar 1. Histogram Data Keterampilan Proses Sains Kelompok Eksperimen Sumber: HasilPengamatan Sendiri

Berdasarkan histogram pada Gambar 1, diketahui bahwa modus lebih besar dari median dan median lebih besar dari mean $(\mathrm{Mo}>\mathrm{Md}>\mathrm{M})$. Data keterampilan proses sains kemudian dikonversikan ke dalam tabel skala penilaian atau kategori skala lima teoritik, nilai rata-rata keterampilan proses sains kelompok eksperimen berada pada kategori sangat tinggi.

Histogram data keterampilan proses sains kelompok kontrol dapat dilihat pada Gambar 2 berikut.

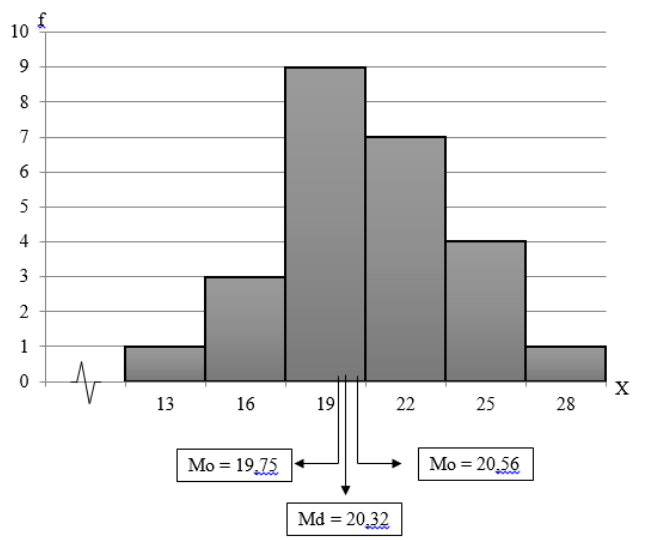

Gambar 2. Histogram Data Keterampilan Proses Sains Kelompok Kontrol 
Sumber: Hasil Pengamatan Sendiri

Berdasarkan histogram pada Gambar2, diketahui bahwa modus lebih kecil dari median dan median lebih kecil dari mean $(\mathrm{Mo}<\mathrm{Md}<\mathrm{M})$. Data keterampilan proses sains kemudiandikonversikan ke dalam tabel skala penilaian atau kategori skala lima teoritik, nilai rata-rata keterampilan proses sains kelompok kontrol berada pada kategori tinggi.

Sebelum melakukan uji hipotesis terlebih dahulu dilakukan uji prasyarat analisis yaitu uji normalitas dan uji homogenitas. Ringkasan hasil uji normalitas sebaran data keterampilan proses sains kelas eksperimen dan kontrol dapat dilihat pada Tabel 2 sebagai berikut.

Tabel 2. Ringkasan Hasil Uji Normalitas Sebaran Data Keterampilan Proses Sains

\begin{tabular}{|c|c|c|c|c|}
\hline No & $\begin{array}{l}\text { Kelompok Data Keterampilan Proses } \\
\text { Sains }\end{array}$ & $\chi_{\text {hutung }}^{2}$ & $\chi_{\text {tabel }}^{2}$ & Status \\
\hline 1 & Eksperimen & 1,650 & 7,815 & Normal \\
\hline 2 & Kontrol & 3,636 & 7,815 & Normal \\
\hline
\end{tabular}

Berdasarkan hasil perhitungan dengan menggunakan rumus chi-kuadrat, diperoleh $X^{2}$ hitung keterampilan proses sains kelompok eksperimen adalah 1,650 dan $X^{2}$ tabel dengan taraf signifikansi 5\% dan $\mathrm{dk}=3$ adalah 7,815. Hal ini berarti, $X^{2}$ hitung keterampilan proses sains siswakelompok eksperimen lebih kecil dari $X^{2}$ tabel $\left(X^{2}\right.$ hitung $<X^{2}$ tabel $)$ sehingga data keterampilan proses sains kelompok eksperimen berdistribusi normal, sedangkan, $X^{2}$ hitung keterampilan proses sainskelompok kontrol adalah 3,636 dan $X^{2}$ hitung dengan taraf signifikansi 5\% dan $\mathrm{dk}=3$ adalah 7,815. Hal ini berarti, $X^{2}$ hiung hasil post-test kelompok kontrol lebih kecil dari $X^{2}$ tabel $\left(\chi^{2}\right.$ hitung $<\chi^{2}$ tabel $)$ sehingga data keterampilan proses sainskelompok kontrol berdistribusi normal.

Setelah dihitung normalitas sebaran data, data keterampilan proses sains kemudian diuji homogenitas. Dalam penelitian ini, uji homogenitas varians dilakukan terhadap varians pasangan antara kelompok eksperimen dan kontrol, Homogenitas data dianalisis dengan uji-F dengan kriteria data homogen jika $F_{\text {hitung }}<F_{\text {tabel. }}$. Ringkasan hasil uji homogenitas varians antar kelompok eksperimen dan kontrol disajikan pada Tabel 3 sebagai berikut.

Tabel 3. Ringkasan Hasil Uji Homogenitas Kelompok Eksperimen dan Kelompok Kontrol

\begin{tabular}{|c|c|c|c|}
\hline Sumber Data & $F_{\text {hitung }}$ & $\begin{array}{l}\mathrm{F} \text { tabel dengan taraf } \\
\text { signfikansi } 5 \%\end{array}$ & Status \\
\hline $\begin{array}{l}\text { Posttest Kelompok Eksperimen dan } \\
\text { Kontrol }\end{array}$ & 1,00 & 2,03 & Homogen \\
\hline
\end{tabular}

Berdasarkan Tabel 3, diketahui bahwa hasil post-testkelompok eksperimen dan kelompok kontrol dengan $\mathrm{db}$ pembilang $=21-1=20 \mathrm{dan} \mathrm{db}$ penyebut $=25-1=24$ pada taraf signifikansi $5 \%$ diketahui $\mathrm{F}_{\text {tabel }}=$ 2,03 danF $F_{\text {hitung }}=1,00$. Hal ini berarti bahwa $F_{\text {hitung }}<F_{\text {tabel }}(1,00<2,03)$ sehingga data kemampuan keterampilan proses sains siswa bersifat homogen.

Berdasarkan uji asumsi analisis data, diperoleh bahwa data keterampilan proses sains kelompok eksperimen dan kontrol berdistribusi normal dan bersifat homogen. Analisis dilanjutkan dengan pengujian hipotesis. Pengujian hipotesis dilakukan untuk mengetahui pengaruh model pembelajaran kooperatif tipe group investigation berbantuan asesmen kinerja terhadap keterampilan proses sains siswa.Pengujian hipotesis dalam penelitian ini menggunakan uji-t untuk sampel independent (tidak berkorelasi). Rumus uji-t untuk sampel yang tidak berkorelasi adalah rumus polled varians karena jumlah sampel kelompok eksperimen tidak sama dengan jumlah sampel kelompok kontrol $\left(\mathrm{n}_{1} \neq \mathrm{n}_{2}\right)$.

Kriteria pengujian adalah $\mathrm{H}_{0}$ ditolak jika $t_{\text {hitung }}>\mathrm{t}_{\text {tabel }}$ dan $\mathrm{H}_{\mathrm{a}}$ ditolak jika $\mathrm{t}_{\text {hitung }}<\mathrm{t}_{\text {tabel. }} \mathrm{t}_{\text {tabel }}$ diperoleh dari tabel distribusi $t$ pada taraf signifikansi $5 \%$ dengan derajat kebebasan $d b=n_{1}+n_{2}-2$. Hasil uji hipotesis disajikan pada Tabel 4 berikut.

Tabel 4. Hasil Uji Hipotesis

\begin{tabular}{lllllll}
\hline Kelompok & $\mathrm{N}$ & Mean & Varians $\left(\mathrm{s}^{2}\right)$ & $\mathrm{Db}$ & $\mathrm{t}_{\text {hitung }}$ & $\mathrm{t}_{\text {tabel }}$ \\
\hline Eksperimen & 21 & 26,14 & 10,35 & 44 & 5,771 & 2,015 \\
\hline
\end{tabular}




\begin{tabular}{llll}
\hline Kontrol & 25 & 20,56 & 10,28 \\
\hline
\end{tabular}

Berdasarkan hasil uji hipotesis pada Tabel 4.9, diketahui bahwa nilai $t_{\text {hitung }}=5,771$ dan $t_{\text {tabel }}=2,015$ untuk db 44 pada taraf signifikansi 5\%. Oleh karena nilai $t_{\text {hitung }}>t_{\text {tabel }}(5,771>2,021)$, maka $\mathrm{H}_{0}$ ditolak dan $\mathrm{H}_{\mathrm{a}}$ diterima. Hal ini berarti bahwa terdapat perbedaan keterampilan proses sains antara kelompok siswa yang dibelajarkan dengan model pembelajaran kooperatif tipe group investigation berbantuan asesmen kinerja dan kelompok siswa yang dibelajarkan dengan pembelajaran konvensional pada siswa kelas $\mathrm{V}$ semester II di SD Gugus II Kecamatan Buleleng tahun pelajaran 2017/2018.

Secara umum, hasil analisis data menunjukkan bahwa terdapat perbedaan keterampilan proses sains antara kelompok siswa yang dibelajarkan dengan model pembelajaran kooperatif tipe group investigation berbantuan asesmen kinerja dan kelompok siswa yang dibelajarkan dengan pembelajaran konvensional. Hasil tersebut didasarkan pada rata-rata skor keterampilan proses sains siswa dan hasil ujit. Rata-rata skor keterampilan proses sains siswa yang dibelajarkan dengan model pembelajaran kooperatif tipe group investigation berbantuan asesmen kinerja adalah 26,00 berada pada kategori sangat tinggi, sedangkan rata-rata skor keterampilan proses sains siswa yang dibelajarkan dengan pembelajaran konvensional adalah 20,80 berada pada kategori tinggi. Berdasarkan hasil analisis data menggunakan uji-t diperoleh $t_{\text {hitung }}=5,771$ dan $t_{\text {tabel }}=2,015$ untuk db 44 dengan taraf signifikansi $5 \%$. Hasil perhitugan tersebut menunjukkan bahwa $t_{\text {hitug }}>t_{\text {tabel, }}$, sehingga $\mathrm{H}_{0}$ ditolak dan $\mathrm{H}_{\mathrm{a}}$ diterima. Adanya perbedaan tersebut menunjukkan bahwa model pembelajaran kooperatif tipe group investigation berbantuan asesmen kinerja berpengaruh terhadap keterampilan proses sains siswa kelas V semester II di SD Gugus II Kecamatan Buleleng Tahun Pelajaran 2017/2018. Perbedaan keterampilan proses sains antara kelompok eksperimen dan kelompok kontrol dikarenakan dalam setiap tahapan pembelajaran model pembelajaran kooperatif tipe group investigation melibatkan siswa secara aktif menggali, membangun, dan mengembangkan serta memberikan kesempatan yang luas bagi siswa untuk mengembangkan keterampilan proses sains.

Pembelajaran dengan model pembelajaran kooperatif tipe group investigation dimulai dengan tahapan grouping yaitu membentuk siswa menjadi beberapa kelompok secara heterogen dan memberikan beberapa topik/permasalahan yang akan dipecahkan dalam kelompok. Dalam pelaksanaannya seluruh siswa dalam kelompok aktif menyampaikan pemikiran masing-masing terhadap permasalahan yang diberikan. "Adanya diskusi kelompok juga dapat melatih keterampilan proses sains yaitu aspek berkomunikasi" (Handari, 2012). Berdasarkan hal tersebut dapat diketahui keterampilan proses sains yang dikembangkan pada tahap ini adalah keterampilan mengomunikasikan.

Tahapan kedua yaitu planning. Dalam tahapan ini, masing-masing kelompok membagi tugas kepada seluruh anggota kelompok, sehingga dapat meningkatkan kerjasama dan partisipasi siswa dalam kelompok. Hal ini sesuai dengan salah satu kelebihan model pembelajaran kooperatif tipe group investigation yaitu secara sosial dapat meningkatkan kerjasama, belajar berkomunikasi yang baik dengan teman sendiri maupun guru, belajar menghargai pendapat orang lain, dan meningkatkan partisipasi dalam membuat keputusan (Shoimin, 2014:81).

Tahapan ketiga yaitu investigation, pada tahapan ini siswa dituntut untuk mengumpulkan informasi dari berbagai sumber untuk menganalisis topik yang akan dibahas. Sumber dapat diperoleh dari buku pelajaran dan percobaan secara langsung. Pada pembelajaran yang terjadi, siswa terlebih dahulu membaca buku pelajaran terkait dengan topik yang akan dibahas. Berdasarkan pengetahuan yang diperoleh dari membaca buku pelajaran, siswa membuat sebuah prediksi terkait dengan topik tersebut. Untuk membuktikan prediksi yang telah dibuat, siswa dalam kelompok melakukan sebuah percobaan. Siswa mempersiapkan alat dan bahan yang diperlukan dan melakukan percobaan sesuai dengan petunjuk LKS. Setelah semua informasi terkumpul, anggota kelompok kembali berdiskusi untuk memperoleh kesimpulan. Dengan demikian, tahapan investigasi dapat mengembangkan keterampilan mengamati, memprediksi, merancang dan melakukan percobaan, dan mengomunikasikan. Temuan ini sejalan dengan Susanti (2013) yang menyatakan "dalam melaksanakan penyelidikan pada pembelajaran IPA siswa dapat melakukan keterampilan proses sains diantaranya siswa dapat mengamati, menggolongkan, memprediksi, merancang dan melakukan percobaan dan mengmunikasikan".

Tahapan keempat yaitu organizing. Pada tahapan ini siswa mendiskusikan hasil penyelidikan terhadap suatu topik dari berbagai sumber dan menyimpulkan hasil penyelidikan. Hasil diskusi kelompok disajikan dalam bentuk laporan tertulis. Penyajian hasil diskusi dalam bentuk laporan tertulis melatih keterampilan mengomunikasikan. Hal ini sejalan dengan temuan Handari (2012) yaitu siswa membuat laporan akhir dri hasil invesrigasi dapat melatih keterampilan mengomunikasikan.

Tahapan kelima yaitu presenting. Pada tahapan ini masing-masing perwakilan kelompok menyampaikan hasil diskusi di depan kelas. Jika ada pendapat yang berbeda ataupun terdapat hal yang tidak dimengerti, siswa diberikan kesempatan untuk bertanya dan menyampaikan pendapatnya. Kegiatan seperti ini akan melatih keterampilan mengomunikasikan. Hal ini sejalan dengan temuan Ulfah, dkk. 
(2014) yaitu "pada tahap presentasi hasil akhir, masing-masing kelompok mempresentasikan hasil investigasi mereka, sehingga keterampilan proses sains yang dilatih adalah keterampilan mengomunikasikan". Tahapan terakhir yaitu evaluating. Pada tahapan ini guru memberikan evaluasi terhadap pembelajaran yang telah berlangsung dengan memberikan beberapa soal yang berkaitan dengan hasil penyelidikan yang telah dilakukan.

Berdasarkan temuan-temuan pada kelompok eksperimen, dapat diketahui bahwa model pembelajaran kooperatif tipe group investigation memiliki keunggulan sehingga tepat digunakan dalam pembelajaran. Kelebihan dari model pembelajaran kooperatif tipe group investigation adalah 1) pembelajaran berpusat pada siswa (student center) yang mengakibatkan siswa aktif dalam menggali, membangun, dan mengembangkan konsep, 2) setiap tahapan pembelajaran melatih keterampilan proses sains seperti keterampilan mengamati, memprediksi, merancang dan melakukan percobaan, dan mengomunikasikan, dan 3) meningkatkan kerjasama, interaksi, partisipasi siswa dalam proses pembelajaran.

Beberapa kelebihan inilah yang mengakibatkan keterampilan proses sains siswa yang dibelajarkan dengan model pembelajaran kooperatif tipe group investigation lebih unggul dibandingkan pembelajaran konvensional. Apalagi dalam pelaksanaannya model pembelajaran kooperatif tipe group investigation didukung dengan asesmen kinerja yang menuntut peran aktif dan mampu meningkatkan motivasi siswa sehingga berimbas pada semakin tingginya keterampilan proses sains yang dimiliki siswa. Hal ini sejalan dengan temuan Ekayogi (2016) yang menyatakan "apabila siswa memiliki motivasi berprestasi yang tinggi untuk berpikir kritis melakukan pengamatan dan penyelidikan dalam bidang keilmuan, akan menyebabkan siswa memiliki keterampilan proses sains yang tinggi". Oleh karena itu, dapat dipahami bahwa penggunaan model pembelajaran kooperatif tipe group investigation berbantuan asesmen kinerja berpengaruh terhadap keterampilan proses sains.

Kondisi siswa yang dibelajarkan dengan model pembelajaran kooperatif tipe group investigation berbantuan asesmen kinerja berbeda dengan kondisi siswa yang dibelajarkan dengan pembelajaran konvensional. Pembelajaran konvensional masih berpusat pada guru. Hal ini sejalan dengan pendapat Santyasa (2005:37) yang menyatakan "pembelajaran konvensional bersifat teacher directed". Siswa kurang diberikan kesempatan untuk berkembang secara mandiri. Kondisi tersebut membuat siswa cenderung pasif. Aktivitas siswa dalam pembelajaran hanya mendengarkan dan menerima materi yang disampaikan oleh guru, dengan kata lain guru menjadi sumber belajar utama.

Adapun langkah-langkah pembelajaran konvensional adalah 1) guru menyampaikan tujuan pembelajaran, 2) guru memberikan informasi tentang materi kepada siswa, 3)tanya jawab, 4) penugasan, dan 5) guru menyimpulkan hasil belajar. Berdasarkan langkah-langkah tersebut, diketahui bahwa pembelajaran konvensional lebih menekankan pada proses transfer pengetahuan dari guru kepada siswa, bukan pada proses menggali, membangun, dan mengembangkan konsep oleh siswa itu sendiri, sehingga pembelajaran menjadi kurang bermakna. Pembelajaran yang demikian kurang memberikan pengalaman kepada siswa sehingga siswa cepat merasa bosan karena rendahnya ketertarikan siswa untuk belajar. Temuan-temuan tersebut membuktikan adanya pengaruh yang berbeda dari penggunaan model pembelajaran kooperatif tipe group investigation dan pembelajaran konvensional dalam pembelajaran.

Hasil penelitian ini sesuai dengan hasil penelitian yang didapatkan oleh Erlinawati dan H. Marhadi (2013) yang menyebutkan bahwa model pembelajaran group investigation dapat meningkatkan hasil belajar IPS dan dapat meningkatkan kualitas pembelajaran siswa. Berdasarkan penelitian tersebut, penggunaan model pembelajaran kooperatif tipe group investigation dalam pembelajaran telah menunjukkan hasil yang positif.

Berdasarkan temuan-temuan yang ada pada penelitian ini, dapat dinyatakan bahwa model pembelajaran kooperatif tipe group investigation berbantuan asesmen kinerja berpengaruh terhadap keterampilan proses sains siswa kelas V semester II di SD Gugus II Kecamatan Buleleng tahun pelajaran $2017 / / 2018$.

\section{Simpulan dan Saran}

Berdasarkan hasil pengujian hipotesis dan pembahasan hasil penelitian, maka simpulan dari penelitian ini adalah terdapat perbedaan keterampilan proses sains antara kelompok siswa yang dibelajarkan dengan model pembelajaran kooperatif tipe group investigation berbantuan asesmen kinerja dan kelompok siswa yang dibelajarkan dengan pembelajaran konvensional pada siswa kelas V semester II di SD Gugus II Kecamatan Buleleng tahun pelajaran 2017/2018. Hal tersebut diperoleh dari hasil perhitungan uji-t dengan $t_{\text {hitung }}=5,771>t_{\text {tabel }}=2,015$ (dengan db 44 dan taraf signifikansi 5\%), sehingga $\mathrm{H}_{0}$ ditolak dan $\mathrm{H}_{\mathrm{a}}$ diterima. Melalui perhitungan rata-rata keterampilan proses sains, diketahui rata-rata skor keterampilan proses sains yang dibelajarkan dengan model pembelajaran kooperatif tipe group 
investigation berbantuan asesmen kinerja adalah 26,14 dan rata-rata skor keterampilan proses sains siswa yang dibelajarkan dengan pembelajara konvensional adalah 20,58. Hal ini berarti rata-rata kelompok eksperimen lebih besar dari pada rata-rata kelompok kontrol $(26,14>20,58)$. Dengan demikian, model pembelajaran kooperatif tipe group investigation berbantuan asesmen kinerja berpengaruh terhadap keterampilan proses sains siswa kelas V semester II di SD Gugus II Kecamatan Buleleng tahun pelajaran 2017/2018.

Berdasarkan simpulan tersebut, maka dapat disarankan kepada (1) seluruh siswa agar selalu terlibat secara aktif dalam pembelajaran sehingga dapat mengembangkan pemahaman dan memperoleh pengetahuan baru melalui pengalaman yang ditemukan sendiri, (2) guru yang menemukan permasalahan yang sama dengan permasalahan penelitian ini khususnya dalam pembelajaran IPA agar merancang pembelajaran dengan menggunakan model pembelajaran kooperatif tipe group investigation, sehingga pembelajaran menjadi lebih bermakna (3) kepala sekolah hendaknya memfasilitasi serta membina para guru dalam memilih dan menerapkan model pembelajaran yang disesuaikan dengan materi ajar dan karakteristik siswa dalam pembelajaran, sehingga kualitas pendidikan sekolah meningkat dan (4) peneliti lain yang berniat untuk mengadakan penelitian lebih lanjut mengenai model pembelajaran kooperatif tipe group investigation disarankan menggunakan penelitian ini sebagai acuan kepustakaan pada variabel yang sama atau berbeda.

\section{Daftar Rujukan}

Bundu, Patta. 2006. Penilaian Keterampilan Proses dan Sikap Ilmiah dalam Pembelajaran Sains Sekolah Dasar. Jakarta: Depdiknas

Ekayogi, I.W., dkk. 2016. Pengaruh Inkuiri Terbimbing, Gaya Kognitif, dan Motivasi Berprestasi terhadap Keterampilan Proses Sains Siswa Kelas V SD. Jurnal Pendidikan dan Pengajaran, Volume 4, Nomor 1.

Erlinawati dan H. Marhadi 2014. Penerapan Model Pembelajaran Kooperatif Tipe Group Investigation untuk Meningkatkan Hasil Belajar IPS Siswa Kelas IV SD Negeri 56 Pekanbaru. Primary, Volume 3, Nomor 1 (hal 9-14).

Handari, dkk. 2012. Penerapan Model Pembelajaran Kooperatif Group Investigation (GI) untuk Meningkatkan Keterampilan Proses Sains Siswa Kelas 5 SMA N 6 Surakarta Tahun Pelajaran 2011/2012. UNS Instutional Respository.Volume 4, Nomor 1.

Kurniasih, Imas., dan Berlin Sani. 2016. Ragam Pengembangan Model Pembelajaran untuk Peningkatan Profesionalitas Guru. Jakarta: Kata Pena.

Marhaeni. 2017. Asesmen Autektik dalm Pembelajaran Bahasa Inggris. Depok: PT RajaGrafindo Persada.

Muliyantini, Putu \& Desak Putu Parmiti Penerapan. 2017. "Model Pembelajaran Group Investigation (Gi) Untuk Meningkatkan Hasil Belajar IPA Kelas V". Jurnal Ilmiah Sekolah Dasar Vol 1, No 2 (2017): Mei 2017

Santyasa, I.W. 2005. Buku Ajar Belajar dan Pembelajaran. Singaraja: Undiksha Press.

Shoimin, Aris. 2014. 68 Model Pembelajaran Inovatif dalam Kurikulum 2013. Yogyakarta: Ar-Ruzz Media.

Sugiyanto, H. 2010. Model-model Pembelajaran Inovatif. Surakarta: Yuma Pressindo.

Susanti, Yusi., dkk. 2013 Pengaruh Model Pembelajaran Kooperatif Tipe Groupp Imvestigation Berdasarkan Keterampilan Proses terhadap Hasil Belajar IPA Siswa Kelas IV SD Gugus 2 Mengwi. Mimbar PGSD Undiksha, Volume 1, Nomor 1.

Trianto. 2010a. Model Pembelajaran Terpadu Konsep, Strategi, dan Implementasinya dalam Kurikulum Tingkat Satuan Pendidikan (KTSP). Jakarta: Bumi Aksara.

Trianto. 2010b. Mendesain Model Pembelajaran Inovatif-Progresif; Konsep, Landasan, dan Implementainya pada Kurikulum Tingkat Satuan Pendidikan (KTSP). Jakarta: Prenada Group. 
Riasi, Putu \& I Gede Raga, I Made Suarjana.2013. “Penerapan Metode Group Investigation Melalui Kegiatan Keterampilan Tangan Untuk Meningkatkan Kemampuan Perkembangan Motorik Halus Anak Di Tk Bhakti Kumara Kalisada". Jurnal Pendidikan Anak Usia Dini Undiksha Vol 1, No 1 (2013): EDISI PERDANA

Undang-undang Republik Indonesia No. 20 Tahun 2003 tentang Sistem pendidikan nasional.Jakarta: Direktorat Pendidikan Menengah Umum.

Ulfah, Arina., dkk. 2014. Pengaruh Model Pembelajaran Group Investigation terhadap Keterampilan Proses Sains pada Materi Koloid di SMA. Jurnal Pendidikan dan Pembelajaran. Volume 3, Nomor 10. 